21 Pietro Aretino, La Talanta, in Giovanna Rabitti, Carmine Boccia, and Enrico Garavelli (eds), Teatro, Vol. 2 (Il Marescalco, Lo Ipocrito, Talanta) (Roma, 2010): 417 (my translation).

22 Castiglione, The Book of the Courtier, 66.

23 Ibid, 369.

24 For an interesting speculation on the action of Marescalco and the carnivalesque aspect of this ducal manipulation, see Deanna Shemek, 'Aretino's Marescalco: Marriage Woes and the Duke of Mantua', Renaissance Studies 16.3 (2002), 366-80.

25 Di Maria, The Italian Tragedy in the Renaissance. Di Maria devotes an interesting and significant discussion to the specific role of sound in the theatre and one work that he examines in detail is Aretino's tragedy, Orazio.

\title{
'What makes thou upon a stage?': Child Actors, Royalist Publicity, and the Space of the Nation in the Queen's Men's True Tragedy of Richard the Third
}

At the opening of one of their signature histories, The True Tragedy of Richard the Third, the Queen's Men go out of their way to reassure their audience that what follows will not be a pretentious, inscrutable art play. Yes, a shieldbearing ghost has just crossed the stage crying out for revenge in Senecan Latin, ${ }^{1}$ and yes, a pair of precocious boys in allegorical women's clothing now claim our attention. ${ }^{2}$ Children of some elitist chapel, perhaps? Students from some privileged school? These were tropes that were current not only in London, but also in venues along the Queen's Men's provincial touring routes where local nobility patronized choirboys as well as adult companies, and schools taught public speaking through play-making. But the boys who start the show do not expect their audience to treat the symbolic neoclassical gestures of those opening moments with reverence. The first boy greets the second with a helpful 'Truth well met', and the second reciprocates, 'Thankes Poetrie'. Then Truth asks Poetry, in teasing reference to the Latin-speaking ghost, 'what makes thou vpon a stage?' Within six lines of the ghost's entrance, we are assured that we will not be abandoned to the pretentious devices of Poetry, who by her own admission makes only 'shadowes' on that stage. 'Then will I adde bodies to the shadowes', Truth responds, 'Therefore depart and giue Truth leave / To shew her pageant' (9-14). It is 
a concrete, self-deflating, funny opening delivered by the most ingenuous members of the company.

Recent work on the Queen's Men's dramaturgy has focused on the role of the company's repertoire in Elizabethan public discourse. Scott McMillin and Sally-Beth MacLean interpret the opening of The True Tragedy as an announcement of the company's intent to 'display the plain, unvarnished substance of history in a form appealing to all the people', a gesture consistent with their mandate, under Leicester and Walsingham, to propagate Elizabethan protestant values of 'substantial truth and plain speech' ${ }^{3}$ Brian Walsh has complicated that claim by demonstrating that the play is not as straightforwardly truthful as its first six lines imply. Poetry does not leave the stage as Truth has requested; so, after some words of exposition and no comment on Poetry's disobedience, Truth invites Poetry to leave with her to allow the 'pageant' to commence $(15,73-4) .{ }^{4}$ The subsequent action Walsh sees as a co-operation between Truth and Poetry, 'the marriage of history and aesthetics', most vividly manifest in the frequent instances of audience address that 'break from the historical era in which the play is set in order to deliver transhistorical insights' to its audience. ${ }^{5}$ The result, he argues, is 'the realization, enabled by the theatrical experience of history, that a sense of the past is always the product of a collaborative effort between those who produce and receive it'. 6 In Walsh's reading, The True Tragedy gives its audience a voice in a new kind of public discourse, one not just about English history, but also about historiography; it is part of an emerging Elizabethan self-consciousness about the process of history-making. ${ }^{7}$ If this is true, then The True Tragedy uses allegory and direct address to incubate what Paul Yachnin has called the politically-oriented, if not yet politically-purposive activities of the emerging Elizabethan public sphere. ${ }^{8}$ It is an agent of political empowerment, 'transgressive of long-standing boundaries of rank, ... personhood, and access to public life' that had hitherto prevented ordinary Elizabethans from access to 'real public speech and action' in 'a sphere defined largely by the social elite';' the Queen's Men's dramaturgy was an essential precursor to 'the most potent engine of social and political change in early modern England': Shakespeare's theatre. ${ }^{10}$ As appealing as this reading is to me, I think it is worth putting some pressure on it, in part because of the strength of McMillin and MacLean's case that the Queen's Men's mandate and economy were importantly different from those of the 1590 s London theatre, ${ }^{11}$ but also because there is more to be said about the company's performance dramaturgy. Theatre is temporal and symbolic, but it is also spatial and embodied, and for the 
Queen's Men, actors - especially child actors - were the central means of engaging their geographically-diverse audiences in the new royalist space they were mandated to establish throughout the nation.

The True Tragedy, assuming it was in the Queen's Men's touring repertoire before it reached print, ${ }^{12}$ was located in inns, inn-yards, churchyards, schools, guildhalls, converted abbeys, and universities; it was performed on scaffolds surrounded by standing audiences, stages with raked seats, raised daises or stages with audiences behind as well as in front, and likely in other arrangements as well. Geographically, it was as far east as Aldeburgh and Norwich; as far north as Newcastle upon Tyne and Carlisle, stopping in York on the way; as far west as Chester and Shrewsbury; and as far south as Plymouth and Dover between 1583 and $1594 .{ }^{13}$ In short, it was everywhere, and every individual place in which the play was performed was already inscribed with the histories, relationships, and allegiances of a unique local community. The amateur religious theatre produced in those communities could take extensive dramaturgical advantage of the singularity and familiarity of the places in which, for example, the civic cycle plays had long been performed; ${ }^{14}$ but the professional patronized touring theatre needed to take a different approach to spatiality in its dramaturgy. The mandate of the touring theatre had always been to entice geographically-dispersed local audiences to form broader allegiances in larger geo-political arenas. ${ }^{15}$ The Queen's Men's patron was the monarch and their arena was the nation; they needed, more urgently than any company before them had, a spatial dramaturgy that did not depend upon place as a primary means of generating meaning for their audiences. The Queen's Men's performance space had to be configured by them before it could be occupied, and configured again and again, as consistently as possible, in every venue in every community the company visited across the geographical expanse that must now be understood as a nation.

How could the Queen's Men start to nationalize local spaces, drawing together, as the company moved from one community to the next, diverse places into a conceptual national space whose principal occupant was the queen? Elizabeth herself, with Leicester and Walsingham's help, had made the first grand gesture in pursuit of that goal by poaching the original members of the Queen's Men (how could the actors refuse?) from the most important touring companies of the day. When the newly-formed Queen's Men arrived in, for example, Norwich in June of 1583, on their inaugural national tour, local audiences already knew many — perhaps most — of the company's members very well, since they had been touring with Leicester's, 
Oxford's, Warwick's, and other companies along routes that had been wellestablished in East Anglia and elsewhere since the 1550s. ${ }^{16}$ But these actors had never before appeared in this exceptional configuration, which united the embodied representatives of a number of influential peers, as well as the regions of their influence and the geographical reach of their tours (which in Leicester's case had extended almost as far as the Queen's Men's would), ${ }^{17}$ into a single corporate body of actors travelling the nation in the livery of the queen. With them as they travelled, the actors brought a monarchist repertoire, a repertoire about the nation that was literally about the nation on account of the travels of the company. The space occupied by a play like The True Tragedy of Richard the Third in any particular town in England was thus primarily and essentially defined by the well-traveled bodies of the actors themselves. As they moved through the country, the Queen's Men's bodies configured and reconfigured in every town a stable space for Elizabeth I's new royalist publicity.

Perhaps the constancy of this space at each stop along the Queen's Men's touring routes invited audiences in one place to consider what other audiences in other places had thought of the actors, the play, the queen, the space of the nation; perhaps it empowered ordinary people with a new sense of belonging and identity shared not just with the queen and her servants but with other ordinary members of the nation. If it did, it was a public space in Yachnin's sense of 'creating the means for [voluntarily] coming out in public': ${ }^{18}$ audiences could voluntarily participate (by paying gate money) in an experience of royalist nationality. ${ }^{19}$ Nonetheless, politically-oriented as that experience may have been, its parameters were very carefully circumscribed - at least for the duration of a performance - to prevent it from developing into voluntary political purposiveness. That is, after a performance we might ask, 'I wonder what they thought of the monarchy when they watched The True Tragedy of Richard the Third in Dover?' or (perhaps with more sense of irony) 'in Gloucester or York?' But during the performance itself, even when we are aware of our fellow audience members' concurrent responses to the play, our primary relationship is with its performers and their characters; otherwise, the play cannot proceed. Consequently, if the play is successful, our investment is primarily affective, rather than reflective; and in the case of the Queen's Men's monarchist repertoire, the affective experience we reflect upon after a performance is one in which (if the play has been successful) there has been only one possible answer to the question, 'what do you think of the English monarchy?' This is particularly true of The 
True Tragedy of Richard the Third, because it uses child actors as the specific subset of the Queen's Men's corporate-body-as-nation to represent the English monarchy in the play.

One of the sources of the Queen's boys' affective impact on stage may have been the sheer novelty of their presence there at all, since they seem to have been an uncommonly large group. McMillin and MacLean argue that a consistent minimum of three boys and two young men were needed to perform almost all of the plays the company published with The True Tragedy in 1594, and that plays published earlier required even more young actors. ${ }^{20}$ These numbers seem very high in the context of the surviving evidence about the participation of young actors in adult professional companies. David Kathman's recent and thorough surveys of apprenticeship and other training records have turned up no new evidence to contradict David Bevington's earlier assessment: in the mid-sixteenth century, female and juvenile roles were often avoided; adult men played female roles when necessary; and all-adult troupes seem to have existed until at least $1576 .{ }^{21}$ Bevington notes a 'trend', as he puts it, that does not begin until 'the 1580s toward increased specialization of boys' roles'. ${ }^{22}$ That trend is reflected in Kathman's evidence, which has so far revealed only one actor formally bound as an apprentice (ie, for a period of several years, usually seven) before the mid-1570s. He was the Queen's Men's Richard Tarlton; aside from Tarlton's apprenticeship, Kathman has found no records of other actors formally apprenticed until 1578, but four apprenticeships between 1578 and 1584, a similar number in the 1590s, and considerable positive evidence for the presence of 'boys' in adult professional companies from the late 1590 s on. ${ }^{23}$ It is probably not coincidental that Tarlton is also 'the earliest professional player whom we can specifically document binding apprentices' in 1582 and $1584,{ }^{24}$ nor that records survive of at least one boy travelling with the Queen's Men in October 1584. ${ }^{25}$ In the early and mid-1580s, audiences in Norwich and elsewhere would have heard of private performances given by companies such as the Children of the Duke of Norfolk's Chapel in his Norwich palace, and they may even have seen performances given by the pupils of schools such as King Edward VI's Grammar School, which had been under the control of the Mayor and Aldermen of Norwich since $1547 .{ }^{26}$ But it is less likely that they were accustomed to seeing large numbers of boy actors in adult touring companies. In 1583 or 1584, and even throughout the 1580s, it may have been spectacular and deliciously witty to open an adult touring company's play with a pair of thirteen- or fourteen-year-old actors mocking the familiar neoclassical repertoires of the 
children's companies from which they had migrated. At a minimum, the gesture emphasized the industry-wide reorganization imposed by the formation of the Queen's Men and placed children - perhaps as a symbol of a united nation's future - firmly at the centre of that project.

It also, of course, emphasized the young actors' incongruity as children in an adult environment. The first dramaturgical gesture the Queen's Men make in The True Tragedy is to draw our attention to the displacement of their children from juvenile classical allegory to mature English history. By doing so, they make their boy actors' identities as children explicit and explicitly different from those of their adult colleagues or their audience: we are invited to acknowledge them as, perhaps, smaller, slighter, lighter-voiced, smoother-skinned, more naive, more vulnerable. ${ }^{27}$ Almost immediately, the company begins to exploit the affective potential of this perception: after a thirteen- or fourteen-year-old actor, whose character is called Truth, has joked about the Senecan ghost that has just crossed the stage, acknowledging and diffusing any ironic cynicism about his name, he turns to the audience and describes the danger facing the children of Edward the Fourth. We have already learned that Edward's brother, Richard, Duke of Gloucester, is as corrupt in mind as he is in body: 'a man ill-shaped, crooked-backed, lamearmed, withall / Valiantly minded, but tyrannous in authority' (59-60). Then, 'Gentiles', Truth warns, in the play's first instance of direct audience address:

two sons of tender age, [and]

Five daughters to comfort the hapless queen, [are] all under the protection of the Duke of Gloucester.

Two sons and five daughters are at the mercy of the monstrous Gloucester, and because we as adults are being looked in the eye by a child and told of their danger, we as the audience become responsible for their well-being. The child actor's portrayal of Truth is not like the performances that will be given by adult actors in this play; his non-fictional identity is more visible than those of the adults, in part because he is less able to conceal his identity than older actors are, in part because his allegorical character is less individuated than a realistic one would be, in part because we wish to see his identity (his charisma is in direct proportion to his youth), and in part because the play's opening parody has encouraged us to see him as a child. As a consequence, his identity as a child actor defines the identity of his character; we are unusually conscious of both his and his character's vulnerability and of 
our own complementary responsibilities as adults. When the child Truth tells us that there are children in danger, even though this child is not a local child, but a child belonging to the queen's official agents deployed, as we all know, to woo us to her cause, The True Tragedy's induction moves us from abstract allegory to personal responsibility for community action in defense of the children of a monarch.

And that is only the induction. Once the boy actors are well-established both as allegories for Truth and Poetry and also as real children, and have been experienced by the audience as the loci of our affective investment in the play's plot about endangered children, the plot that the boys have described to us is launched. The boys themselves return to the stage to give bodies to the endangered young princes and to the messengers who eventually launch the play's epilogue on the history of the English monarchy. This is not the doubling pattern proposed by McMillin and MacLean and followed by Walsh, but it is textually possible and does not increase the minimum number of actors needed to perform all the play's roles. It also takes advantage of Kathman's evidence (which was not available to McMillin and MacLean) that professional 'boy' actors were twelve at youngest, but more often between thirteen and twenty-four, so there is no need to assume, as McMillin and MacLean did, that important female roles were played by 'prepubescent' boys. McMillin and MacLean offer:

[Youth]: Poetry. Page. 2 Messenger [final scene].

[Prepubescent boy]: Truth. Queen Mother. Attendant (Richard). Soldier.

[Prepubescent boy]: Shore's Wife. Prince Edward. Attendant

(Buck[ingham]). George Stanley.

[Prepubescent boy]: Hursly. Duke of York. Attendant (Richard). Report.

[Prepubescent boy]: [Princess] Elizabeth. Attendant (Richard). Attendant (Buck[ingham]). ${ }^{28}$

As an alternative, I argue:

[Youngest apprentice]: Young George Stanley, Attendant (Buckingham). [Young apprentice (say 13-14)]: Truth, York, Messenger 1 (final scene).

[Young apprentice (say 13-14)]: Poetry, Edward, Messenger 2 (final scene).

[Young adult apprentice (say 15 or older)]: Queen Mother, Shore's Wife, Attendant (Richard), Attendant (Buckingham).

[Young adult apprentice (say 15 or older)]: Elizabeth, Hursly, Attendant (Buckingham), Attendant (Richard). 
My casting breakdown creates a hierarchy of vulnerabilities and monarchist associations, with the most junior performer in the role of the child George Stanley, his father's 'sweete boy' and 'aged ioy' (2125-7), held hostage by Gloucester to prevent Lord Stanley from fighting against him, and presumed dead after Lord Stanley does join Richmond at the Battle of Bosworth. Next in the hierarchy are the boys who play Truth, Poetry, and the princes, who, true to the fears they have confided to us, are murdered at their uncle's command. Their vulnerability is reinforced just before their deaths by the ironic juxtaposition of their bodily youth against the mature care and sympathy they show one another. The younger York wants to comfort his older brother during their imprisonment in the Tower of London, innocently asking their murderer to 'tell my Kingly brother some mery storie ... for thou seest he is melancholy' (1266-7). Soon after, the older brother shields the younger from the knowledge of their imminent deaths, deciding not to press further when no one - not even the audience - supports his prayer that 'from murther and slaughter, good Lord deliver us'. When no help comes, he casts their plight in as ordinary terms as he can for his little brother's benefit: 'come brother,' he says, 'we will go to bed' (1290). It is significant, too, that unlike Shakespeare's version of the same plot, this play stages the deaths of the boys. The murderers are conscious of the boys' fears: 'didst thou mark how the King started when he heard my name?' asks the aptly-named Will Slawter, 'What will he do when he feeles me?' (1304-5); and in our final image of them before their deaths, the boys are sleeping sweetly (1310). To continue the affective journey, in the final sequence of The True Tragedy, the same two boy actors play the two unnamed messengers who deliver the young George Stanley to safety, in a deus ex machina gesture that recalls the power that Truth and Poetry had in the induction to 'give bodies to ... shadows'. Young George recounts his own rescue, the new King Henry VII binds up the final threads of the plot, and the messengers launch their metatheatrical direct-address history of the monarchy from this time to our own, beginning, 'Thus Gentles may you heere beholde, the ioyning of these Houses bothe in one'. Their account is taken up at the accession of Mary by the pair of actors who appear immediately below them in the hierarchy of vulnerabilities, those who play Princess Elizabeth (soon to be Henry's queen) and her mother Queen Elizabeth (both of which characters also function as references to the reigning Elizabeth I). The final stage image of The True Tragedy is of four young people telling the glorious history of the post-Plantaganet nation in direct address to the audience (2165-2224). 
The True Tragedy of Richard the Third is designed to locate its audience's primary affective response to the play in the persons of the young actors who play Truth and Poetry in its induction. The emphasis placed there on their identities as children appealing to the audience for protection for children becomes the most salient attribute of their characters as princes. The deaths of the two boys carry the personal emotional weight of the murder of children whom the audience has come to know and ought to have protected. Because the boys are also the rightful heirs to the English throne, the audience's personal grief is bound up inextricably with royalist politics: we feel a love for these representatives of monarchy as keenly as we feel love for children - perhaps our own children — and we are consequently as personally invested in the integrity of the state as we are in our own local and personal interests. Our affective loyalty to the Crown is modeled and magnified by Lord Stanley's heroic sacrifice of his own son, young George, in the service of the true king, our monarch's ancestor; and our loyalty is rewarded when all three dead children are returned to us as George and the Messengers in a symbolic resurrection of English youth, innocence, loyalty, and monarchy. When they are joined by other young people to speak the epilogue, the play creates a moving embodiment of nation-as-future, a gesture of unity and hope that we see in the modern world when children's choirs sing national anthems. Possibly, because the gesture was made in direct address, the play created for its audience the affective impression of a new community united, if only for those few closing moments, in a conversation about their loyalty to the historical nation now young again. If that was the case, perhaps the most important action of The True Tragedy took place off stage, in the shifting allegiances of its audience, making possible the unified future it predicted as it recreated its affective monarchist space in town after town along the Queen's Men's extensive touring routes. But there was no room for reflection in that experience; The True Tragedy's acts of direct address did not constitute a discourse of the kind Walsh implies, in which its audiences had a voice. Rather, The True Tragedy compelled its audiences' affections by means of a conversation with endangered children, in a dramaturgical gesture very different from the erudite and sometimes cynical dramaturgies that would be practiced by children's companies for decades to come. It is very difficult to avoid caring for vulnerable children; very difficult to dash their naive hopes; and very difficult to boo them off the stage.

It is possible, of course, that the play failed. It may be that the induction's joke about boys in allegorical clothing left audiences cold in Ipswich, Aldeburgh, 
Kirtling, and Norwich; in Abingdon, Gloucester, Bath, and Bristol, the boys may have been pelted with rotten fruit; perhaps the same fate met them in Canterbury, Faversham, Dover, Leicester, Nottingham, Rye, Shrewsbury, Marlborough, London, Whitehall, Saffron Walden, Cambridge, York, Southampton, and Dover. ${ }^{29}$ But if Christopher Goodman, a Protestant divine from the city of Chester can be trusted, professional players were welcomed in his community at least in part because of the attractions of the 'vayne pastance and vnprofitable spectackles' they offered. ${ }^{30}$ And according to Goodman, reluctant local authorities tolerated them, 'fearinge the displeasure of such noble personages (to whom the aforesaide ... Players ... doe appertaine and weare theire lyveries)'. This letter was written in 1583; there is perhaps some support for Goodman's argument in the fact that by 1596 , despite the city council's ban on all plays, the mayor of Chester was nonetheless allowed to pay most patronized touring companies 6s $8 \mathrm{~d}$ and the Queen's Men 20s when they arrived in the city. ${ }^{31}$ In other towns, the Queen's Men imposed in other ways: in Norwich in 1583 , for example, they jumped off the stage to pursue a man for not paying to enter the yard where they were performing; they started a brawl that spilled out onto the street and resulted in the death of a bystander; and the local authorities seem to have banded together to protect them, allowing them to post bail for each other, ignoring the fact that they never returned to the city to stand trial, and welcoming them back to perform, apparently without any judicial consequence, within a year. ${ }^{32}$ In Norwich, if your answer to the question 'what do you think of the monarchy?' was the wrong one, you might not have felt that membership in the new royalist public was entirely voluntary. A newly politically-purposive theatre-going public may have been developing in 1590s London, as Yachnin, Walsh, and other commentators have argued, 33 but outside of London, in the 1580s and perhaps the 1590s as well, the impulse of professional dramaturgy was at least in this case to stabilize and circumscribe, rather than to multiply and open, new spaces for public discourse. Instead of a proto-democratic space for voluntary association, the Queen's Men and their boys, when they performed The True Tragedy of Richard the Third in provincial town after provincial town, created something that more closely resembled a royal nation than a public. When they put the canonical history of the nation into the bodies and voices of vulnerable children, they gave it a space that transcended locality, politics, and dissent, a royal nation that must be felt and belonged to everywhere. 


\section{Notes}

I am grateful to Alan C. Dessen, JoAnna Dutka, Erika T. Lin, Robert Ormsby, Steven Mullaney, and especially to Paul Yachnin. This research grew out of my 2007 production of The True Tragedy of Richard the Third for the University of Toronto's Shakespeare and the Queen's Men project, and was further encouraged by McGill University's Making Publics project. Parts of it were presented at the Making Theatrical Publics panels at the 2011 meeting of the Renaissance Society of America, and at the Shakespeare in Performance Working Group at the 2009 meeting of the American Association for Theatre Research. It has been supported by the University of Waterloo's Newberry-Folger travel grant program.

1 'Cresse cruor sanguinis, satietur sanguine cresse, / Quod spero scitio. O scitio, scitio, vendicta'. All citations from this play refer to through line numbers (TLNS) in Jennifer Roberts-Smith and Dimitry Senyshyn (eds), The True Tragedie of Richard the Third (Quarto) (Queen's Men Editions, 2012), http://qme.internetshakespeare.uvic.ca /Foyer/plays/TTR3.html. Regarding this reference to Seneca, which appears at TLN 6-7, see Benjamin Griffin, Playing the Past: Approaches to English Historical Drama 1385-1600 (Woodbridge, Suffolk and Rochester, New York, 2001), 69.

2 The allegorical figures of Truth and Poetry were typically represented as female in contemporary iconography. For examples, see Alciato's Emblematum liber (1531), the earliest European emblem book, in Alciato at Glasgow, Glasgow University Emblem Site (Glasgow, n.d.), http://www.emblems.arts.gla.ac.uk/alciato/index.php; see also Cesare Ripa's 1593 descriptions, in their earliest English translations, in Pierce Tempest (trans.), Iconologia: or Moral Emblems, by Cæsare Ripa (London, 1709), The English Emblem Book Project (Pennsylvania, 2004), http://emblem.libraries.psu.edu /Ripa/Images/ripa0ii.htm.

3 Scott McMillin and Sally-Beth MacLean, The Queen's Men and Their Plays (Cambridge, 1998), 33.

4 Brian Walsh, Shakespeare, The Queen's Men, and the Elizabethan Performance of History (Cambridge, 2009), 82-3.

5 Ibid, 100.

6 Ibid, 101.

7 Ibid, especially chapters 1 and 2, 10-73.

8 See Paul Yachnin, 'Performing Publicity', Shakespeare Bulletin 28.2 (2010), 201-19, 212.

9 Paul Yachin, 'What Is a Public?', Making Publics (Montreal, 2012), http://www .makingpublics.org. 
10 Yachnin, 'Performing Publicity', 201.

11 See McMillin and MacLean, The Queen's Men, 11-12, 16-36, 71. For a counterargument, less convincing, see W.R. Streitberger, 'Adult Playing Companies to 1583', Richard Dutton (ed.), The Oxford Handbook of Early Modern Theatre (Oxford, 2009), 19-38, 25. Barbara Palmer demonstrates the economic benefits of touring in 'On the Road and on the Wagon', Helen Ostovich, Holger Schott Syme, and Andrew Griffin (eds), Locating the Queen's Men 1583-1603: Material Practices and Conditions of Playing (Farnham, Surrey and Burlington, VT, 2009), 27-39.

12 The True Tragedy or an earlier version of it had likely been performed for many years before 1594. Estimated dates of composition and/or performance range from late 1588 to 1586 to some time before 1583. See Griffin, Playing the Past, 65 n3; and Walsh, Shakespeare, The Queen's Men, 103.

13 See McMillin and MacLean, The Queen's Men, 67-82. On playing conditions in noble houses and town halls, see Palmer, 'On the Road and on the Wagon', Ostovich, Syme, and Griffin, Locating the Queen's Men, 27-39. On inn-playing conditions, see David Kathman, 'London Inns as Playing Venues for the Queen's Men', in Ostovich, Syme, and Griffin, Locating the Queen's Men, 65-75. On raked seating and 'channel' staging in university venues, see Alan Nelson, Early Cambridge Theatres (Cambridge, 1994). The Queen's Men's tour stops are recorded in REED: Patrons and Performances; and in McMillin and MacLean, 'Map 3', The Queen's Men, 50.

14 See, for example, David Mills, Recycling the Cycle (Toronto, 1998), 173-8, the section titled 'The City as Actor'.

15 On the general aims of the patronized theatre, see Suzanne R. Westfall, Patrons and Performance: Early Tudor Household Revels (Oxford, 1990), 154; and Suzanne R. Westfall, “'He Who Pays the Piper Calls the Tune”: Household Entertainments,' Dutton, Oxford Handbook, 264-79.

16 Sussex' men was another source of Queen's Men actors, but was less well-travelled. See McMillin and MacLean, The Queen's Men, 39-40 and, for actors' names and former affiliations, 12 and Appendix C, 194-7.

17 Ibid, Map 1, 19.

18 Yachnin, 'Performing Publicity', 212.

19 By the late 1540s, touring companies in Norwich, for example, were charging entrance fees to individuals in addition to the fees paid by the civic authorities. See David Galloway (ed.), ReED: Norwich (Toronto, 1984), 20, 25.

20 McMillin and MacLean's differentiation between youths and boys is articulated in The Queen's Men, 107; their casting analysis of The True Tragedy appears in Appendix B, The Queen's Men, 190-1; on minimum casting requirements, see 102-8. 
My breakdown has the additional advantage of reconciling The True Tragedy's casting requirements with those of the other plays the Queen's Men published in 1594, which seem to have required three 'boys'.

21 See David Bevington, From Mankind to Marlowe: Growth of Structure in the Popular Drama of Tudor England (Cambridge, MA, 1962), 74-8. Streitberger reviews this evidence in 'Adult Playing Companies to 1583', 23.

22 Bevington, From Mankind to Marlowe, 78.

23 David Kathman, 'Grocers, Goldsmiths, and Drapers: Freemen and Apprentices in the Elizabethan Theater', Shakespeare Quarterly 55.1 (2004), 1-49; David Kathman, 'How Old Were Shakespeare's Boy Actors?' Peter Holland (ed.), Shakespeare Survey 58: Writing About Shakespeare (Cambridge, 2005), Cambridge Collections Online, n.p.

24 Kathman, 'Players, Livery Companies, Apprentices', Dutton, Oxford Handbook, 418-19; Kathman, 'Grocers, Goldsmiths, and Drapers', Appendix.

25 He was paid by Sir Francis Willoughby at Wollaton Hall; see McMillin and MacLean, The Queen's Men, 47.

26 The Children of Norfolk's Chapel performed for the Norwich mayor and aldermen at Christmas in 1564 and 65; see Galloway, REED: Norwich, 51, 54-5. See also Westfall's discussion in " $H e$ Who Pays the Piper Calls the Tune": Household Entertainments', 268. King Edward VI's Grammar School, now called Norwich School, was the descendant of Bishop Herbert de Losinga's Episcopal Grammar School, founded in about 1096; see 'Heritage', Norwich School (Norwich, 2012), www.norwich -school.org.uk. Grammar School boys were paid by the city in 1546-7, 1564-5, and 1565-6; see Galloway, REED: Norwich, 1.xxxi, 21, 52, 54. The duke of Norfolk also kept an adult company; they performed at the Common Hall, Norwich in 1556-7; the Falcon Inn and the Common Hall, Cambridge, and somewhere in Exeter in 1557; the Town Hall in Lewes, Sussex in 1557-8; and the Common Hall in Norwich again in 1558-9; see REED: Patrons and Performances.

27 Alan C. Dessen argues that there is no historical evidence for the kind of meaningful doubling I propose in 'Conceptual Casting in the Age of Shakespeare: Evidence from Mucedorus', Shakespeare Quarterly 43.1 (1992), 67-70. There is, however, ample evidence that audiences perceived actors' and characters' identities simultaneously, perhaps most famously in the incident in Tarlton's Jests that describes Tarlton playing a scene with himself in the Queen's Men's Famous Victories of Henry the Fifth; see O.J. Halliwell (ed.), Tarlton's Jests (Nendeln, 1966), 25. Walsh notes that 'Tarlton [draws] on his own celebrity as a means of highlighting the play's status as a play for comic effect'; see Shakespeare, The Queen's Men, 61. See also Alan Armstrong, "'What is Become of Bushy? Where is Green?": Metadramatic Reference to 
Doubling Actors in Richard II', Paul Menzer (ed.), Inside Shakespeare: Essays on the Blackfriars Stage (Selinsgrove, PA, 2006), 149-55.

28 McMillin and MacLean, The Queen's Men, 107; Kathman, 'How Old?'

29 Ibid, 175.

30 A 'pastance' is, according to the Oxford English Dictionary, a 'recreation', likely etymologically derived from the Middle French 'passetemps' ('pastance', n.).

31 The Chester Assembly Book specifies that the fees are paid 'because yt shall not be alledged that this restraynte is for sparinge of the treasury of this Citie'; it is possible that these were payments not to play. See Baldwin, Clopper, and Mills, ReED: Cheshire, 1.202-3, 1.259.

32 Roberts-Smith, 'The Red Lion and the White Horse: Inns Used by Patronized Performers in Norwich, 1583-1624', Early Theatre 10.1 (2007), 110-20.

33 Walsh works forward from the Queen's Men's True Tragedy and Famous Victories of Henry the Fifth to Shakespeare's Richard III and Henry V in successive chapters of Shakespeare, the Queen's Men. See also Griffin's account of the refinement, secularization, and politicization of the genre of the history play since before the Reformation, in chapters 2 and 3 of Playing the Past, 22-46. I disagree with his characterization of The Famous Victories of Henry the Fifth as a London play (its audience was much more likely primarily a provincial one), but support his basic contention that sixteenth-century plays treated time and space in complex and sometimes internally inconsistent ways.

\section{'The Great Choreographer': Embodying Space in Fuenteovejuna}

Social dances embody and perform kinesthetic structures of courtesy and courtship. The relative positions of dancers, their gestures, eye contact and posture, and manipulation of personal accoutrements (hats, gloves, fans, etc.), communicate at once both social hierarchies and personal desire. Furthermore, floor patterns, large and small group forms, contact between male and female dancers, and varying musical rhythms all contribute to the degrees and modes of human interaction, whether legitimized or transgressive. This was no less true in early modern Europe as it is today as is evident in the various treatises on dance in Europe such as Raoul Feuillet's Chorégraphie, ou l'art de decrier la dance, Pablo Minguet e Irol's Arte de danzar a la francesa, and Juan de Esquivel Navarro's Discursos sobre el arte del danzado. Nevertheless, of all of the branches of performance historiography, historical dance 